\title{
Capacity for War: Preparing the British Aviation Industry in the 1920s ${ }^{1}$
}

Dr Matthew Powell, Teaching Fellow PBS @ Cranwell

\begin{abstract}
:
This article explores the relationship between the Air Ministry and the British airframe industry in the 1920s and the efforts undertaken to increase the capacity of the industry to increase output in the event of a national emergency. It charts the negotiations between the Society of British Aircraft Constructors (SBAC) and Air Commodore L.E.O. Charlton in 1925. It argues that the Air Ministry were looking at the strategic problems that would be faced if the industry was not able to increase production while the SBAC were only concerned with their survival and looked to exploit the Air Ministry's concerns.
\end{abstract}

The Royal Air Force (RAF) ended the First World War with the largest air force then known to the world. The 1920s, however, was a period of retrenchment, defence and consolidation for the fledgling independent force, and this would have disastrous consequences for the aviation industry that had developed as a result of war demand. The global strategic outlook, based as it still was around European rather than American power, was one of relative peace and this allowed the governments of the 1920s to reduce spending on defence and concentrate on domestic social programmes. ${ }^{2}$ Investigations were undertaken by the Air Ministry to establish the capacity of the aviation industry in Britain and how best it could be prepared to upscale its production in the event of an emergency and during the initial phase of a state of war. Peter Fearon has claimed that 'there is no evidence of a detailed questionnaire being sent out or of consultations with the SBAC [Society of British Aircraft Constructors] ...' as a part of this process. ${ }^{3}$ It quickly became clear that the aviation industry in Britain simply did not have the capacity or capability to increase production in an emergency. This article will demonstrate this by looking at the investigations of Air Commodore L.E.O. Charlton who worked closely with the industry body the SBAC during 1925.

Due to limitations of space it will not look at activity within the aero-engine industry but will focus on the relationship between the SBAC and the Air Ministry. It will not look at individual firms as they negotiated en masse through the SBAC, who would discuss issues 
with the Air Ministry as they arose and where they affected all or a majority of their members. It will argue that the Air Ministry attempted to increase the manufacturing ability of the aviation industry in Britain to meet a future emergency when quantity production would be required. Charlton was prevented in this attempt by the SBAC who simply looked at how it would affect individual constructors rather than a national effort. Whilst it is understandable for the industry body to protect the survival of individual members as viable businesses, the Air Ministry attempted to increase the viability of many manufacturers by improving their production capabilities. The only credible counter argument that the SBAC offered that stands up to any interrogation is the potential effect such a move by the Air Ministry would have on the design teams in major firms if work was taken from them and sub-contracted out to others.

This paper will also highlight an understudied aspect of the history of the aviation industry in Britain. The focus of historians has been the unpreparedness of the both the Air Ministry and aviation industry for expansion in the 1930s, in response to policy decision made by both Stanley Baldwin and Neville Chamberlain. ${ }^{4}$ This article will demonstrate that the Air Ministry had a degree of knowledge of the required scope for the aviation industry to increase its production capacity. There would be a remarkable shift in priorities after the Second World War when the prospect of nuclear war meant that there would be little need for largescale mass production capacity. ${ }^{5}$ The increasing cost and technological complexity of aircraft production meant that future designs would require international collaboration, something that continues to this day thereby negating even further the requirement for manufacturers to have spare capacity in the case of emergency. The continual advancement of technology in aircraft production, that often renders aircraft obsolescent before they leave the production line and remains one of the biggest issues that plagues the procurement of new aircraft in the 
contemporary environment. It further highlights the difficulties faced meeting the challenge of contingency planning in an age of austerity.

Defence spending in Britain was reduced in line with the thinking of the Ten Year Rule, instituted in $1919 .{ }^{6}$ Restrictions on defence spending would be a concurrent theme during the majority of the RAF's existence. Whilst there has been much debate between historians regarding the overall impact of the Ten Year Rule, it is outside the scope of this paper to discuss this in depth; suffice to say that it led to decreased budgets for the United Kingdom's (UK) three military Services. ${ }^{7}$ This was one of the most difficult times for the RAF since its creation in 1918, having to defend itself as an independent Service and demonstrate its relevance in the wider strategic environment. This is something that the RAF has had to do in order to justify its continued existence. Despite Air Marshal Sir Hugh Trenchard, (Chief of the Air Staff) wishing to spend the majority of the meagre budget (this fell to $£ 9.4$ million in 1923) given to the RAF on constructing physical infrastructure leading to a specific air force culture being developed, new aircraft were still required, and old aircraft would require reconditioning to remain serviceable. ${ }^{8}$ This need for new aircraft was heightened after the deterioration in relations between the UK and France over Germany's refusal to pay the Versailles Treaty reparations and the subsequent French invasion of the Ruhr valley in an attempt to extract payment in goods. ${ }^{9}$ It was realised, after the diplomatic crisis between London and Paris in the wake of the Ruhr invasion, that the French Air Force vastly outnumbered the RAF and could unleash untold damage on major cities without the fear of massive retaliation to deter them. ${ }^{10}$ Whilst there was little fear of French attack from the Chiefs of Staff, this feeling was not shared by the politicians, it was this fear that led to plans for an expansion of the RAF being made. ${ }^{11}$ 
It had been decided by the British government prior to the First World War that it would not create public factories for the construction of aircraft or aero-engines. It would, instead, rely on private industry to supply their requirements. This was despite the financially precarious nature of the majority of British aircraft constructors at this time. ${ }^{12}$ There was, initially, relatively heavy investment in the Royal Aircraft Factory (formerly the Royal Balloon Factory) as a research and design hub that, under its flamboyant director, Lieutenant-Colonel Mervyn O'Gorman, also began to build aircraft. Whilst O'Gorman did not see this as impinging on the burgeoning private constructors, this was not how the industry saw the Royal Aircraft Factory and there was a level of distrust between the government began to sour relations, who as effectively the sole customer of the industry felt it could arrange production as it wished, and the industry itself who wanted to retain a degree of independence in their affairs. ${ }^{13}$ As Harald Penrose has noted 'O'Gorman had no intention of competing with the British manufacturers, for as an imaginative, energetic, and intellectual leader he was as convinced of the value of private enterprise as any man. ${ }^{14}$ The research that emerged from the Royal Aircraft Factory would have been of invaluable use to the private constructors, but they were keener to find solutions by trial and error rather than via scientific methods. ${ }^{15}$ As the First World War progressed, the demand for aircraft and aero-engines increased exponentially. This led the pioneering private constructors to expand in size to meet the demand and new firms entered the market as it became clear that current capacity was not enough. In terms of aero-engines, there was very little expansion in domestic production and, the majority of aero-engines were of French manufacture. From 1918, the RAF realised that such reliance had to be avoided if another major conflict was to break out. ${ }^{16}$ The aviation industry as whole expanded to meet the wartime demand as best they could, but inevitably demand outstripped industrial capacity to supply and delays were experienced. This issue was not aided by the competing demands of the War Office and Admiralty for aircraft from the 
same suppliers and the centralisation of all aircraft procurement to prioritise requirements and delivery was one of the reasons noted for the creation of an independent air force in discussions that took place between 1917 and $1918 .{ }^{17}$

With the end of the First World War and the natural decline in the quantity of orders for aircraft and aero-engines, many manufacturers found life difficult and struggled to survive. This was particularly the case when the Excess Profits Tax initiated in 1915 was continued until 1920 by the post-war government of David Lloyd George. ${ }^{18}$ The Excess Profits Tax was designed as a quell to public opinion that armament manufacturers had been able to profit excessively from war production. ${ }^{19}$ Many firms, particularly within the aviation industry, did not have the necessary capital to meet this continuing tax burden. The Air Ministry was fully aware that, with the declining viability of firms and the subsequent reduced industrial base they would be unable to re-equip the RAF force quickly in the event of a diplomatic emergency or war with another industrialised nation. It was not until late in 1924, however, that this was formally accepted by the Air Ministry and a scheme designed to plan for this eventuality. Lieutenant-Colonel H.W.S. Outram wrote in a loose minute to Charlton that he saw three stages of expansion necessary for achieving greater production in an emergency. These stages were 'The expansion to a maximum output of the firms engaged on aeronautical supplies in peace-time'; followed by 'The formation of those firms into Master Firms'; and finally, 'The formation of National Aircraft Factories'. ${ }^{20}$

Outram expected that under the first stage production could be expected to double within a month of the emergency. This was followed by the proviso that sufficient raw materials and sundry items such as instruments must be available, orders had to be distributed to a large number of firms, that adequate space existed at the firms and that the industry had the ability to produce the designs of other firms. ${ }^{21}$ These were similar provisos to those that would be 
faced during the rearmament of the 1930s, where firms could not justify the investment in extra factory floor space simply for a short-lived rise in demand. ${ }^{22}$

Ensuring firms had the necessary stock of raw materials, with the investment in capital, to be able to react to an emergency would be a tough sell for the Air Ministry. The firms would not want to sink money into extra stock that would degrade over time for an emergency that may or may not materialise. In order to resolve this issue, the firms, through the SBAC, suggested that the Air Ministry should purchase the stock that would be held at the aircraft

manufacturers on a 'pay on consumption basis'. ${ }^{23}$ This alleviated all the financial risk to the firms and placed it all on the Air Ministry and, as a result, the tax payer. The SBAC claimed that holding this emergency stock would create increased costs involved in assessing and turning the timber stock to prevent degradation that would also fall to the Air Ministry. The firms of the SBAC were willing to accept this cost as they already had staff employed in this role and so would only have to accept a negligible cost to ensure the quality of the timber. This is a major example of the SBAC looking to exploit the fears of both the government of the day and the Air Ministry over the industry's ability to upscale its production to either save or make money. By holding the stock on site on a 'pay on consumption' basis and having the Air Ministry re-stock any timber used, they would only have to pay for what was consumed and not have invested capital into excessive stock that may lie unused, appearing as a negative on their balance sheets.

These were not the only aspects to be considered by the Air Ministry or the industry. In order to allow the firms the opportunity to train and retain the necessary skeleton production staff, they would require orders over a long period of time. The SBAC were of the opinion that a substantial number of orders over a three- to five-year period would suffice. ${ }^{24}$ Whilst, on the surface, this may seem like a reasonable request from the industry's body, it must be taken within its historical context where the budgets available for new aircraft were severely 
limited. New aircraft could not be ordered simply to keep firms in business and the Air Ministry recognised this when they established the ring of aircraft constructors to whom they would farm out enough production and reconditioning contracts to keep the firms in business. With the priority of Trenchard being on physical infrastructure for the RAF and not the continual purchase of aircraft, there was little that the Air Member for Supply and Research (AMSR) or the Principle Supply Officer (PSO) could do.

In an attempt to get around this situation Charlton as PSO suggested that ten per cent of all aircraft should be replaced on a yearly basis in order to provide sufficient orders for the firms to not only retain their skilled labour workforce but also their design teams that were the ultimate key to their long-term viability. ${ }^{25}$ Basing his assumptions on a five-year production plan, Charlton began to sketch out a peace-time production scheme that would enable the aviation industry to expand if and when necessary to meet the increased demand. The production plan was based around the need to build 25,000 aircraft and 30,000 aero-engines in the first twelve months of an emergency. ${ }^{26}$ The need to prepare for an emergency was brought home to the Air Ministry through a realisation of the unfavourable strategic situation which they faced in the air in comparison to their closest potential enemy. The French Air Force, in the early 1920s was the largest in the world and posed a direct theoretical threat to London and other major British cities. This had a sobering effect on the government of the day, who initiated a 52-squadron construction programme not to defend the UK but to carry out equally heavy attacks on enemy centres of gravity such as industrial areas and cities. ${ }^{27}$ This reflected the relative focus of the RAF for offensive operations. Although never ultimately realised, it quickly became clear that the aviation industry was incapable of producing the numbers required to meet the demand for an increased air force. This realisation was one of the driving factors behind Charlton's investigations to discover what the potential capacity of the industry would be in the event of an emergency. Two 
questionnaires were sent out to the various manufacturing firms. The first set out to establish current production levels and capacity for extra work in peace-time and the second how quickly they would be able to expand and how much they would be able to produce in a time of national crisis. The firms were, naturally enough, reluctant to provide the information to the second questionnaire, mostly out of fear that if they over-estimated their figures this would be used as a stick with which to beat them if an emergency did arise. The firms were also instructed that their plans for expansion of premises and plant should be made on the basis that, in an emergency situation, they would receive financial support from the government. ${ }^{28}$ The problems that they anticipated regarding access to sufficient raw materials and the availability of skilled labour were the very real conundrums faced subsequently implementing rearmament schemes between 1936 and 1939. Despite the efforts of Charlton to explain that they should base their figures on a plentiful supply of raw materials and skilled labour, the firms remained intractable. Firms with experience of production in the First World War and the massive increases in production required to support the Royal Flying Corps, Royal Naval Air Service and RAF were fully aware that no guarantees could be made for either of these elements and felt that they would still lay themselves open to public criticism. $^{29}$

The SBAC did show a degree of flexibility in trying to make themselves better prepared for expansion in an emergency, but it would come at a price to the Air Ministry. It was suggested that in order to achieve the possible position, the Air Ministry should be ordering a minimum of 5 per cent of the 25,000 aircraft that it was estimated would be required. ${ }^{30}$ This could be spread throughout the whole industry. Although, as Sebastian Ritchie has rightly acknowledged, this would not have closed the enormous gulf between what the Air Ministry believed was required in an emergency and the industry's ability to meet that demand in the 
first twelve months of an emergency or state of war, it would have provided key indicators to further quantify industry shortfalls. ${ }^{31}$

Charlton believed that a five-year production plan would give the Air Ministry two main advantages. The first was that the individual firms would now be given licence to invest in tools and jigs on a larger scale, knowing that they would see a return on their investment and more. This would reduce the cost of individual aircraft and give the firms themselves the vital experience of limited but important mass production techniques that would ease the transition from piece work when required. ${ }^{32}$ The second was that firms would be more likely to increase their production of all-metal aircraft. This was a very recent development in the mid-1920s and very few firms had made the transition from wood, string and canvas aircraft. ${ }^{33}$ All-metal aircraft would constitute the key technological development in aircraft construction in the inter-war period.

Without detailed feedback and figures from the industry, however, Charlton would not be in a position to develop an outline scheme that optimised both the process and rate of industrial expansion. In order to achieve this, and make the transition from peace to war time production as seamless as possible, Charlton proposed that 'Any aircraft or engine finding a place on it [the production programme] should alone be produced during peace and on the outbreak of war should go, immediately, into quantity production. ${ }^{34}$ In doing so, he demonstrated an awareness of industrial concerns. In the initial stages of the expansion, the aircraft constructors would be faced with enough challenges and anticipated a marked drop in production whilst they re-organised, without the added difficulty of having firms produce aircraft that they were unfamiliar with.

There were also decisions to be made regarding how far governments contracts should be spread amongst the varying quality of manufacturers that made up the industry. ${ }^{35}$ Concentrating orders within a few proven firms would leave them in a healthier financial 
position and able to retain both their production and design staffs. ${ }^{36}$ It would, however, come at the cost of reducing the overall size of the industry as the lesser manufacturers found themselves either made insolvent or bought out by the larger firms. In an attempt to prevent this happening, a smaller production scheme, to be instituted when a new aircraft was first being built, was proposed to allow the Air Ministry to spread peace-time work amongst various firms in order to allow them to gain the necessary experience required to increase their capacity as well as that of the whole industry. In this scheme, the first six to nine machines produced would then be subject to service tests. Following this, the next machine (the seventh or the tenth depending on the order) would then be constructed according to the Master Tracings that had previously been prepared. The ownership of the Master Tracings would pass to the Air Ministry but would remain in the possession of the designing firm for updates and corrections. The Master Tracings would then be used to create blueprints that could be assigned to different manufacturers on a sub-contract basis. ${ }^{37}$ This idea was again met with a degree of disdain from the SBAC, as was nearly every attempt by the Air Ministry to increase the amount of sub-contracting that took place between firms. They saw this as an attempt to artificially keep the industry larger than could be supported by current demand and were extremely unhappy at work being taken away from reliable firms whose design teams had produced superior aircraft. This attitude from the SBAC is understandable from an industrial body point of view but it failed to grasp that for wider politico-strategic reasons the Air Ministry was needed to enhance the abilities of as many manufacturers as possible.

Certain areas of the Air Ministry, particularly those connected with supply understood, as early as the mid-1920s that the next conflict would be industry- and resource-centric relying on economic power for survival and eventual victory. The SBAC was unable to see past the balance sheet for the current financial year. 
The eventual plans for an expanded aviation industry in Britain during a period of emergency or, indeed, war, were similar to those that would be instigated during rearmament in the midto late-1930s. There were two distinct phases envisioned for the ultimate expansion of the aviation industry after the full expansion of those already supplying and bidding for production contracts with the Air Ministry. Outram noted that ' ... each designing firm [Master Firm] in an emergency would have certain geographically convenient other Works allotted to it, who would construct and supply to the parent firm components, details and other units. ${ }^{38}$ The Master Firm would remain responsible for the final completed aircraft. This would entail that the jigs and machine tools necessary for the manufacture of various aircraft parts would have to be spread far and wide according to need, and it was not clear where the cost for this would fall. Given the general attitude of the SBAC firms, it is highly unlikely that they would be willing to invest in the necessary outlay and infrastructure if they were unable to utilise it for themselves. The legal ownership of these important items, as well as their maintenance and repair would likely be a further sticking point between the SBAC and Air Ministry had this scheme been implemented. The final stage of the proposed expansion of the aviation industry would be the creation of so-called National Factories. ${ }^{39}$ These would go on to be called the Shadow Factories of the rearmament period and would operate in a similar fashion, drawing in firms that were not involved in aviation to expand the capacity available to the Air Ministry.

Ultimately, these plans never had to be put into action as a major diplomatic emergency did not occur in the 1920s and the Air Ministry was able to ensure the survival of the aviation industry through the farming out of limited existing and forthcoming orders to a select group of firms that, they hoped, would provide the physical and intellectual foundations for expansion. This, however, was one of the first examples of a military Service looking to anticipate requiring extra capacity within an industry and looking to implement plans to 
increase this. Capacity studies and explorations are now standard practice within manufacturing and the work of Charlton can provide guidance and direction when working with third tier producers. Many of the issues that Charlton encountered in dealing with the SBAC, whose major concern was for their members short-term future rather than the longterm security of the nation, re-emerged during the rearmament period in the 1930s. Aviation firms were loath to invest in either the Shadow Factory scheme or in expanded premises and tools, jigs and extra staff for what could be a very short-lived rearmament drive. During his time as PSO, Charlton sought to work as best he could with the SBAC but almost continually met with a wall of defiance that looked to protect profits over national security. The SBAC tried to exploit the Air Ministry's concerns over the preparedness of the aviation industry for expansion in order to improve the health of their individual businesses and underlying industrial stability. Whilst the survival of the industry as a whole was important to national security and strategy, its ability to expand rapidly when required was of greater importance still because, as the events of the next decade revealed, whilst it could be kept alive when demand was low, large-scale expansion of the aviation industry represented a complex and enduring challenge. The Air Ministry and SBAC approached the problem of expansion in the aviation from tow completely different perspectives: the industry was looking to the shortterm to ensure their survival, whereas the Air Ministry were sought to protect and enhance the security of the nation as a whole.

\footnotetext{
${ }^{1}$ I would like to express my gratitude to Dr Steve Paget, Dr Frank Ledwidge, Dr Andrew Conway and Mr Mal Craghill at the Royal Air Force College, Cranwell for their insightful and constructive comments on previous drafts of this article and my former colleagues of the Materials Department at Meritor (HVBS) Ltd for the explanation of pay on consumption processes.

${ }^{2}$ David French, The British Way in Warfare 1688-2000 (Boston, Sydney and Wellington: Unwin Hyman, 1990), p. 179.

${ }^{3}$ P. Fearon, 'Aircraft Manufacturing' in Neil K. Buxton and Derek H. Aldcroft (eds), British Industry between the Wars: Instability and Industrial Development 1919-1939 (London: Scholar Press, 1979) Fearon 'Aircraft Manufacturing', p.224. The questionnaire and the details of the discussion between the Air Ministry and the SBAC can be found at The National Archives (TNA) AIR 2/266. In the early 1920s SBAC membership had fallen to eighteen firms. Keith Hayward, The British Aircraft Industry (Manchester and New York: Manchester University Press), p. 11.
} 
${ }^{4}$ Robert Paul Shay Jr., British Rearmament in the Thirties: Politics and Profits (Princeton, NJ: Princeton University Press, 1977). G.C. Peden, British Rearmament and the Treasury: 1932-1939 (Edinburgh: Scottish Academic Press, 1979). Colin Sinott, The Royal Air Force and Aircraft Design: Air Staff Operational Requirements 1929-1939 (London and Portland, Oregon: Frank Cass, 2001).

${ }^{5}$ David Edgerton, Wafare State: Britain, 1920-1970 (Cambridge: Cambridge University Press, 2006), p. 233.

${ }^{6}$ The Ten Year Rule was a policy instituted in 1919 in the wake of the First World War whereby the three fighting Services were to base their spending plans on the basis that there would be no major European war for the next ten years. This was not rescinded until 1932.

${ }^{7}$ John Ferris, 'Treasury Control, the Ten Year Rule and British Service Policies, 1919-1924', The Historical Journal (Vol. 30, No. 4, December 1987), p. 867. Brian Bond and Williamson Murray, 'The British Armed Forces, 1918-1939' in Allan R. Millett and Williamson Murray (eds), Military Effectiveness Vol. II: The Interwar Period (New Edition) (New York: Cambridge University Press, 2010), p. 101.

8 John Alexander, 'Despised and Neglected? British Fighter Defence, 1922-1940', Air Power Review (Vol. 18 No. 2, Summer 2015), pp. 165-6.Fearon, 'Aircraft Manufacturing', p. 221. David Ian Hall, Strategy for Victory: The Development of British Tactical Air Power, 1919-1943 (London and Westport, CT: Praeger Security International, 2008), p. 16.

${ }^{9}$ Colin Sinnott, The Royal Air Force and Aircraft Design, 1923-1939: Air Staff Operational Requirements (London and New York: Routledge, 2014), p. 6.

${ }^{10}$ N. H. Gibbs, Grand Strategy Vol. I: Rearmament Policy (London: Her Majesty’s Stationary Office, 1976), p. 40.

${ }^{11}$ H. Montgomery Hyde, British Policy between the Wars 1918-1939 (London: Heinemann, 1979), pp. 110-1.

${ }^{12}$ Harald Penrose, British Aviation: The Pioneer Years 1903-1914 (London: Puntam, 1967), p. 302.

${ }^{13}$ John H. Morrow Jr, The Great War in the Air: Military Aviation from 1910 to 1921 (Washington and London: Smithsonian Institute Press, 1993), pp. 21, 28, 42.

${ }^{14}$ Penrose, British Aviation, p. 282.

15 Ibid. pp. 206, 282.

${ }^{16}$ While France is not explicitly mentioned in the correspondence in the file TNA AIR 2/266, it is a fair assumption that the prospect of a war on the European continent sufficiently spooked the Air Ministry into action.

${ }^{17}$ Tami Biddle, 'Learning in Real Time: The Development and Implementation of Air Power in the First World War', in Sebastian Cox and Peter Gray (eds), Air Power History: Turning Points from Kitty Hawk to Kosovo (Oxon and New York: Frank Cass, 2002), p. 11.

${ }^{18}$ Sebastian Ritchie, Industry and Air Power: The Expansion of British Aircraft Production, 1935-1941 (London and New York: Routledge, 1997), p. 8. Anthony J. Arnold, 'A Paradise for Profiteers? The Importance and treatment of profits during the First World War', Accounting History Review (Vol. 24, No. 2-3, 2014), p. 69. ${ }^{19}$ Arnold, 'A Paradise for Profiteers?', pp. 61-9.

${ }^{20}$ TNA AIR 2/266, Loose Minute from Lieutenant-Colonel H.W.S. Outram to Charlton, 22 December 1924. ${ }^{21}$ Ibid.

${ }^{22}$ Robin Higham, 'Government, Companies and National Defense: British Aeronautical Experience, 1918-1945 as the Basis for a Broad Hypothesis', The Business History Review (Vol. 39, No. 3, Autumn 1965), p. 331.

${ }^{23}$ TNA AIR 2/266, Minutes of a Meeting held at 1 Albermarle Street, London (SBAC), 23 April 1925.

${ }^{24}$ Ibid. Note of Points Raised at a Meeting of Committee of Management of the Society of British Aircraft Constructors, 4 February 1925.

${ }^{25}$ Ibid. Unsigned Memorandum to the Director of Contracts (Air Ministry), 6 November 1924.

${ }^{26}$ Ibid. Meeting of Charlton with the Management Committee of the Society of British Aircraft Constructors, 4 February 1925.

${ }^{27}$ Tami Davis Biddle, Rhetoric and Reality in Air Warfare: The Evolution of British and American Ideas about Strategic Bombing, 1914-1945 (Princeton, NJ and London: Princeton University Press, 2002), p. 84.

${ }^{28}$ TNA AIR 2/266, Letter from B.E.H. Clowery to the Society of British Aircraft Constructors, 23 February 1925.

${ }^{29}$ Ibid. Letter from Boulton Paul Limited to Charlton, 9 March 1925.

${ }^{30}$ Ibid. Memorandum by Charlton to Air Member for Supply and Research, 17 April 1925.

${ }^{31}$ Ritchie, Industry and Air Power, p. 28.

32 TNA AIR 2/266, Memorandum by Charlton to Air Member for Supply and Research, 17 April 1925.

${ }^{33}$ Hayward, The British Aircraft Industry, p. 15.

34 TNA AIR 2/266, Memorandum by Charlton, 26 September 1925; Letter from Charles V. Allen (Secretary SBAC) to Squadron Leader Rasmusen, 15 April 1925.

${ }^{35}$ Ibid. Memorandum by Charlton, 26 September 1925.

${ }^{36}$ Ibid. 
${ }^{37}$ Ibid. Recommendations of a Meeting to Consider the Question of Master Tracings in Relation to a "Production Programme", 13 February 1925.

38 Ibid. Loose Minute from Outram to Charlton, 22 December 1924.

${ }^{39}$ Ibid. 